\title{
Tracheostomy in Covid-19 Patients: Surgical Concerns and Considerations
}

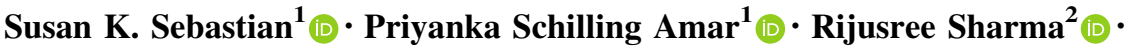 \\ Manu Gupta ${ }^{3} \cdot$ Satish Ramesh $^{4}$ (I)
}

Received: 25 December 2020/Accepted: 11 January 2021/Published online: 29 January 2021

(C) Association of Otolaryngologists of India 2021

\begin{abstract}
Tracheostomy in Covid-19 patients is an aerosol generating procedure putting health care workers at great risk. Retrospective study of tracheostomy in ten Covid-19 patients with ARDS using modifications of the surgical techniques revealed its efficacy in limiting the risks of spread to health care workers and improving surgical outcome.
\end{abstract}

Keywords Covid -19 - Tracheostomy .

Health care workers

Susan K. Sebastian

drsusanjohn@rediffmail.com; drsusanks@gmail.com

Priyanka Schilling Amar

priyankaschilling@gmail.com

Rijusree Sharma

rijushri@rediffmail.com

Manu Gupta

manugupta@live.com

Satish Ramesh

satishpriya0529@gmail.com

1 Department of ENT and Head \& Neck Surgery, St. Stephen's Hospital, 110054 Delhi, India

2 Department of Critical Care Medicine, St. Stephen's Hospital, Delhi 110054, India

3 Department of Internal Medicine, St. Stephen's Hospital, Delhi 110054, India

4 Department of Anaethesia, St. Stephen's Hospital, Delhi 110054, India

\section{Introduction}

Covid-19 infection can have a variety of presentations ranging from mild upper respiratory infection to severe pulmonary damage leading to acute respiratory distress syndrome requiring mechanical ventilation [1]. With a significant number of patients requiring prolonged ventilation we have experienced a surge in the number of tracheostomies.

However, tracheostomy is an aerosol-generating procedure and places healthcare workers $(\mathrm{HCW})$ in an environment of high exposure. Although multiple Otolaryngology-Head and Neck Surgery societies have developed protocols for tracheostomy in Covid-19 patients, [2, 3] guidelines have changed since the beginning of the pandemic. This paper aims to discuss our experience in performing surgical tracheostomies in ten Covid-19 patients at our institution.

\section{Case Series}

From 15th May 2020 to 20th September 2020, St.Stephen's Hospital, Delhi, India, admitted 106 adult patients with Covid-19 who required critical care support. 52 patients required prolonged mechanical ventilation for acute respiratory distress syndrome (ARDS). Of this, ten patients (7 males, 3 females) with ARDS who underwent a surgical tracheostomy are included in this retrospective analysis. A summary of the patient demographics, Acute Physiology and Chronic Health Evaluation-II(APACHE-II) score, comorbidities, tracheostomy related complications and final outcome are included in Table 1 Seven patients had diabetes mellitus and four were hypertensive while three patients did not have any comorbidity. The mean 
Table 1 Clinical profile

\begin{tabular}{|c|c|c|c|c|c|c|c|c|c|}
\hline No & Age & Sex & Comorbidities & $\begin{array}{l}\text { Covid related } \\
\text { complications }\end{array}$ & $\begin{array}{l}\text { Appache- } \\
2 \text { score }\end{array}$ & $\begin{array}{l}\text { Days of } \\
\text { Mechanical } \\
\text { ventilation at } \\
\text { tracheostomy }\end{array}$ & $\begin{array}{l}\text { Ionotropic } \\
\text { support/ renal } \\
\text { replacement } \\
\text { therapy }\end{array}$ & $\begin{array}{l}\text { Complications } \\
\text { of } \\
\text { tracheostomy }\end{array}$ & $\begin{array}{l}\text { Final } \\
\text { Outcome }\end{array}$ \\
\hline 1 & 60 & $\mathrm{~F}$ & $\begin{array}{l}\text { Diabetes, } \\
\text { Hypertension }\end{array}$ & $\begin{array}{l}\text { Pneumonia, ARDS, } \\
\text { Diabetic ketoacidosis, } \\
\text { Septic shock,Acute } \\
\text { kidney injury }\end{array}$ & 18 & 22 & $\begin{array}{l}\text { Ionotropic } \\
\text { support, renal } \\
\text { replacement } \\
\text { therapy }\end{array}$ & None & Expired \\
\hline 2 & 56 & M & $\begin{array}{l}\text { Diabetes, } \\
\text { Hypertension }\end{array}$ & $\begin{array}{l}\text { Pneumonia, ARDS, } \\
\text { Pneumomediastinum }\end{array}$ & 9 & 10 & Nil & None & Recovered \\
\hline 3 & 48 & M & None & $\begin{array}{l}\text { Pneumonia. ARDS. Acute } \\
\text { kidney injury, } \\
\text { Myocarditis }\end{array}$ & 16 & 16 & $\begin{array}{c}\text { Ionotropic } \\
\text { support }\end{array}$ & Canula & \\
\hline None & Expired & & & & & & & & \\
\hline 4 & 38 & M & Diabetes & $\begin{array}{l}\text { Pneumonia, ARDS, Fungal } \\
\text { Septicemea, } \\
\text { Pneumomediastinum }\end{array}$ & 15 & 7 & $\begin{array}{c}\text { Ionotropic } \\
\text { support }\end{array}$ & $\begin{array}{l}\text { Intra-operative } \\
\text { bleeding }\end{array}$ & Recovered \\
\hline 5 & 50 & M & None & $\begin{array}{c}\text { Pneumonia, ARDS, Shock, } \\
\text { Deep vein thrombosis, } \\
\text { Pneumomediastinum }\end{array}$ & 15 & 9 & $\begin{array}{c}\text { Ionotropic } \\
\text { support }\end{array}$ & None & Expired \\
\hline 6 & 59 & $\mathrm{~F}$ & $\begin{array}{l}\text { Diabetes, } \\
\text { Hypertension }\end{array}$ & $\begin{array}{l}\text { Pneumonia, ARDS, } \\
\text { Myocarditis, Shock, } \\
\text { Pneumomediastinum }\end{array}$ & 22 & 15 & $\begin{array}{r}\text { Ionotropic } \\
\text { support, }\end{array}$ & $\begin{array}{l}\text { Difficult } \\
\text { decanulation }\end{array}$ & Recovered \\
\hline 7 & 67 & M & Diabetes & $\begin{array}{l}\text { Pneumonia, ARDS, Shock, } \\
\text { Acute kidney injury }\end{array}$ & 14 & 13 & $\begin{array}{l}\text { Ionotropic } \\
\text { support, renal } \\
\text { replacement } \\
\text { therapy }\end{array}$ & $\begin{array}{l}\text { Difficult } \\
\text { decanulation }\end{array}$ & Expired \\
\hline 8 & 51 & M & Diabetes & $\begin{array}{c}\text { Pneumonia, ARDS, Acute } \\
\text { kidney injury, Shock, } \\
\text { pneumomediastinum }\end{array}$ & 25 & 19 & $\begin{array}{l}\text { Ionotropic } \\
\text { support. renal } \\
\text { replacement } \\
\text { therapy }\end{array}$ & None & Expired \\
\hline 9 & 62 & $\mathrm{~F}$ & $\begin{array}{l}\text { Diabetes, } \\
\text { Hypertension }\end{array}$ & $\begin{array}{l}\text { Pneumonia, ARDS, Shock, } \\
\text { Pneumomediastinum }\end{array}$ & 10 & 11 & $\begin{array}{r}\text { Ionotropic } \\
\text { support }\end{array}$ & $\begin{array}{l}\text { Canula } \\
\text { blockage }\end{array}$ & Recovered \\
\hline 10 & 48 & M & Diabetes & Pneumonia, ARDS, Shock & 9 & 13 & $\begin{array}{r}\text { Ionotropic } \\
\text { support }\end{array}$ & None & Recovered \\
\hline
\end{tabular}

ARDS $=$ Acute Respiratory Distress Syndromme; Apache score $=$ Acute physiology and chronic health evaluation score

APPACHE-II Score was 15.5(standard deviation $=5.15$ ). Six patients developed spontaneous pneumomediastinum during the course of illness. Nine patients required ionotropic support and three were on renal replacement therapy. The mean time from intubation to tracheostomy formation was 12.8 days (standard deviation $=5.20$ ). The ventilation details are included in Table 2.

The PPE used by the procedure team include N95 mask, surgical cap, goggles and face shield, fluid-resistant disposable surgical gown, double gloves and shoe covers. Several modifications of the technique were undertaken during the covid-19 surgical tracheostomy. Before the start of surgery, pre-oxygenation with $100 \%$ oxygen was done after clearing the oropharynx and hypopharynx of secretions using a Yankauer suction tip via an inline suction system. The patient was then fully paralysed to abolish swallowing and cough reflexes so as to minimise aerosol production. Initial advancement of the endotracheal tube was done adequately so that the cuff reached beyond the site of the proposed tracheostomy window and was hyperinflated to isolate the lower airway. Ventilation was temporarily ceased prior to the creation of the tracheostomy window, the cuff was deflated and endotracheal tube was withdrawn upto a level above the tracheal opening and the cuff was inflated and ventilation resumed again. After a cuffed non-fenestrated tracheostomy tube was introduced and connected to the ventilatory circuit, endotracheal tube was carefully removed under cover of a drape sheet and immediately discarded in a closed container. It is essential to secure the position of tracheostomy tube to prevent its dislodgement and high chance of exposure of 
Table 2 Ventilation details

\begin{tabular}{|c|c|c|c|c|c|c|c|c|c|c|}
\hline \multirow[t]{2}{*}{ No } & \multicolumn{3}{|c|}{ PEEP (kPa) } & \multicolumn{3}{|c|}{$\mathrm{FiO}_{2}(\%)$} & \multicolumn{3}{|c|}{$\mathrm{PaO}_{2}: \mathrm{FiO}_{2}$ ratio $(\mathrm{mm}$ of $\mathrm{Hg})$} & \multirow{2}{*}{$\begin{array}{l}\text { Total days } \\
\text { of MV }\end{array}$} \\
\hline & $\begin{array}{l}\text { Day } 1 \\
\text { MV }\end{array}$ & $\begin{array}{l}\text { Tracheostomy } \\
\text { day }\end{array}$ & $\begin{array}{l}\text { Day } 5 \\
\text { Tracheostomy }\end{array}$ & $\begin{array}{l}\text { Day } 1 \\
\text { MV }\end{array}$ & $\begin{array}{l}\text { Tracheostomy } \\
\text { day }\end{array}$ & $\begin{array}{l}\text { Day } 5 \\
\text { Tracheostomy }\end{array}$ & $\begin{array}{l}\text { Day } 1 \\
\text { MV }\end{array}$ & $\begin{array}{l}\text { Tracheostomy } \\
\text { day }\end{array}$ & $\begin{array}{l}\text { Day } 5 \\
\text { Tracheostomy }\end{array}$ & \\
\hline 1 & 10 & 6 & 6 & 1 & 0.45 & 0.30 & 50 & 271 & 340 & 47 \\
\hline 2 & 12 & 6 & 10 & 1 & 0.50 & 0.50 & 51.8 & 146 & 282 & 26 \\
\hline 3 & 11 & 7 & 5 & 0.90 & 0.60 & 0.55 & 75 & 86 & 123 & 23 \\
\hline 4 & 10 & 6 & 7 & 1 & 0.50 & 0.50 & 65 & 146 & 64 & 15 \\
\hline 5 & 10 & 8 & 7 & 0.75 & 0.60 & 1 & 81 & 140 & 67 & 15 \\
\hline 6 & 7 & 5 & 6 & 1 & 0.35 & 0.35 & 67 & 194 & 297 & 43 \\
\hline 7 & 9 & 8 & 9 & 1 & 0.55 & 1 & 70 & 101 & 44 & 20 \\
\hline 8 & 12 & 7 & 7 & 1 & 0.40 & 0.40 & 94 & 122 & 157 & 30 \\
\hline 9 & 12 & 7 & 5 & 1 & 0.55 & 0.35 & 40 & 130 & 74 & 62 \\
\hline 10 & 11 & 6 & 5 & 1 & 0.40 & 0.60 & 54 & 122 & 155 & 20 \\
\hline
\end{tabular}

PEEP $=$ Positive End Expiratory Pressure: $\mathrm{FiO}_{2}=$ Fraction of inspired Oxygen: MV = Mechanical Ventilation

HCW. Good haemostatic control was reached, since most of these patients were on heparin.

None of the healthcare professionals have developed clinical symptoms of Covid-19 during the follow-up period of four weeks. The mortality rate among Covid-19 patients requiring invasive ventilatory support in our intensive care unit during this period was $63 \%$ while among the tracheostomised patients, it was 50 per cent.

\section{Discussion}

The benefits from tracheostomy in ventilated patients with Covid-19 are far greater than in the traditionally ventilated patients due to the extensive pulmonary injury that requires lengthy ventilation and the frequent chances of reintubation during the weaning phase because of laryngeal oedema, muscle weakness and vicid lower respiratory secretions which are difficult to expel. Earlier recommendation was to defer tracheostomy beyond 21 days of intubation [3] when the chance of disease spread became less [4] and patient's prognosis became clearer. In patients with severely compromised gas exchange placement of the tracheostomy tube can be unsafe as they do not tolerate a loss of positive airway pressure during the procedure [2]. Also, these patients may require invasive ventilation in the prone position in the early phase, making a tracheostomy contraindicated [5].

Angel et al. [6] and the Concensus group [2] are in favour of an earlier tracheostomy around the 10th day of intubation which also helps in maximising the availability of ICU resources. In our series the indication and timing of tracheostomy was decided on a case to case basis following evaluation by the multidisciplinary team. Seven cases underwent the procedure between the 9 th and 15 th day. Three patients remained unstable for prolonged periods requiring high ventilatory and ionotropic support making an early tracheostomy risky. In this series, patients who had a favourable outcome were tracheostomised by the 15th day of mechanical ventilation. In our opinion, the ideal time for tracheostomy is between the 10th and 15th day of invasive ventilation which coincides with the expected decrease in infectivity of the virus [4].

Covid-19 tracheostomy should be carried out in a negative pressure room with minimum health care workers and a skilled surgical team to minimize the operating time and potential complications[2]. Modifications of the procedure were undertaken in view of the compromised respiratory status and to limit the aerosol exposure of the HCW. In our opinion these measures and proper PPE use has helped in limiting the risks of spread.

Except for excessive intraoperative bleeding in one case, the patients in our study group had no significant tracheostomy related complications making it a safe procedure in critically ill Covid -19 patients. A raised APACHEII score and spontaneous pneumothorax in our group of patients were indicators of worsening of the disease and adverse prognosis. Organ support requirements were also high in this group. Our observations suggest that tracheostomy should not be delayed in Covid -19 patients on mechanical ventilation, for fear of potential risk of disease spread that can be controlled by effective infection control methods and modifications of the procedure techniques. We need further evaluation using a larger cohort of patients for the outcome analysis of tracheostomy in Covid-19 patients. 


\section{Conclusions}

Tracheostomy is a safe and beneficial procedure in Covid19 patients on mechanical ventilation. Meticulous procedure planning and infection control methods are effective in reducing the risk to health care workers.

Author Contributions 1.Susan K Sebastian. Substantial contributions to the conception of the work, the acquisition, analysis, interpretation critical analysis of data and drafting the work. Approved the version to be published and agreed to be accountable for all aspects of the work. 2. Priyanka Schilling Amar. Substantial contributions to the acquisition, analysis, interpretation and revision of data Approved the version to be published and agreed to be accountable for all aspects of the work. 3 Rijusree Sharma. Substantial contributions to the conception of the work, interpretation and analysis of data. Approved the version to be published and agreed to be accountable for all aspects of the work. 4. Manu Gupta. Substantial contributions to the acquisition, analysis, interpretation and analysis of data. Approved the version to be published and agreed to be accountable for all aspects of the work. 5. Satish Ramesh Substantial contributions to the analysis, interpretation of data and drafting the work. Approved the version to be published and agreed to be accountable for all aspects of the work.

Funding We have not received any funding or financial support from any source for the conduct of this study. The authors have no relevant financial or non-financial interests to disclose. The authors have no conflicts of interest to declare that are relevant to the content of this article. All authors certify that they have no affiliations with or involvement in any organization or entity with any financial interest or non-financial interest in the subject matter or materials discussed in this manuscript. The authors have no financial or proprietary interests in any material discussed in this article.

\section{Compliance with Ethical Standards}

Conflict of interest Authors declare no conflict of interest.

Ethical Approval Institutional Ethics Committee clearence obtained. No: SSHEC/R0149 This study is a retrospective analysis. Hence it does not have a CTRI Number. All procedures performed in this study are in accordance with the ethical standards of the institutional research committee and with the 1964 Helsinki declaration and its amendments. Informed consent has been waived.

\section{References}

1. Huang C, Wang Y, Li X et al (2020) Clinical features of patients infected with 2019 novel coronavirus in Wuhan. China Lancet 395:497-506

2. McGrath BA, Brenner MJ, Warrillow SJ (2020) Tracheostomy in the COVID-19 era: global and multidisciplinary guidance. Lancet Respir Med. https://doi.org/10.1016/S2213-2600(20)30230-7. publishedonlineMay15

3. Miles BA, Schiff B, Ganly I, Ow T, Cohen Eet al (2020) Tracheostomy during SARS-CoV-2 pandemic: Recommendations from the New York Head and Neck Society. Head Neck 42(6):1282-1290

4. Zou L, Ruan F, Huang M et al (2020) SARS-CoV-2 viral load in upper respiratory specimens of infected patients. N Engl J Med 382:1177-1179

5. Volo T, Stritoni P et al (2020 July) Elective tracheostomy during COVID-19 outbreak: to whom, when, how? Early experience from Venice. Italy Eur Arch Otorhonolaryngol 12:1-9

6. Angel L, Kon ZN, Chang SH et al (2020) Novel percutaneous tracheostomy for critically ill patients with COVID-19. Ann Thorac Surg 110(3):1006-1011

Publisher's Note Springer Nature remains neutral with regard to jurisdictional claims in published maps and institutional affiliations. 